\title{
How Much Output should be Produced by the Firm? An Analysis
}

\author{
Muhammad Junaid Qureshi \\ M. S. Economics, National College of Business Administration and Economics, Lahore, Pakistan.
}

Umair Siddiqui

MBA Student, Institute of Management Sciences, Bahauddin Zakariya University, Multan, Punjab, Pakistan

Hafiz Fasahat

MBA Student, Institute of Management Sciences, Bahauddin Zakariya University, Multan, Punjab, Pakistan

Naveed Cheema

MBA Student, Institute of Management Sciences, Bahauddin Zakariya University, Multan, Punjab, Pakistan

\begin{abstract}
In this study, the main objective of the firm is to determine output and price level; we have taken the time series data of the firm and have applied the ordinary least square technique. We find out the equilibrium point of the firm where marginal revenue is equal to marginal cost and at that point firm earn the maximum profit and we also determine the price level of the firm. The output level that the firm should produce would be of 3922 units, at this point its total cost is 1131611 , total revenue is 1115890 , marginal revenue is 308.6689 , marginal cost is 308.6702 and optimal price is 284.5206 .
\end{abstract}

Keywords: Price and Output Determination, Empirical Study, MR = MC

\section{Introduction}

A firm consists of all the actual potential buyers and sellers of a particular product. Firm's structure refers to the competitive environment in which the buyers and sellers of the product operates. The best level of output of the firm is at the point where plant to produce the best level of output. If profits can be earned in industry more, firms will enter in the industry in the long run until all profits are eliminated.

If input prices are constant the firm supply curve obtained by the horizontal summation of the competitive firm supply curve. In this study we bring together demand analysis and production and cost analysis in order to analyses how price and output are determined. We begin this study by identifying the various industries. We examine and show how the equilibrium price and quantity are determined and also how the firm determines the optimum level of output. The process by which price and outputs are determined in the real world is strongly affected by the structure of the firm. The main objective of the firm is to determine the output and to know how much level of output there it will be profit maximize. If the marginal cost is above the marginal revenue then the firm will face loss. In this situation firm can shut down its production units

Apart from introduction, the rest of the paper is arranged as follows: section II portrays review of the literature; section III discusses data and methodological issues. Results are interpreted in section IV. Finally, conclusions and policy implications are given in section $\mathrm{V}$.

\section{Literature Review}

Faith (2005) presented a study to determine the output level and price level using the time series data. Keeping in view the importance of estimation of output and price level we presented some empirical evidences. At Keynesian theory assert that various micro economics factors, include process of production bottlenecks, law of diminishing returns and wage bargaining are the main determinants of the price level. Keynes owns formulation about the theory of the price level initiates the transmission mechanism of money to economic activity. An increase in money supply leads to decrease in the interest rate, which in turn leads to increase in investment. For the period of 1980 to 2000, they used multivariate co integration technique. They conclude that the pricing behavior of the sub sector of the Turkish manufacturing industry by using Johnson's co integration analysis. In 
accordance with the expectation of the Keynesian it has been found that prices and demand and unit wage cost demonstrated integration relation in 14 out of 16 sub sectors.

William (2011) used binary flow chart to study price stimulation. The elements uncovered include both market factors and organizational factors. Testing the model for predictive accuracy and simulative ability is reviewed. Marketing implications include a legitimate defense against charges of collusion in price setting in an oligopoly and better understanding of market reaction to organizational components. They concluded that the implications for marketing policy and strategy overlap those of organizational theory and those of organizational behavior theory of the firm. Prominent in the market area are possible defense against charges of collusive in price settings of collusive in price setting

\section{Data and Methodology}

The data of 26 quarters has been collected from the company and this collected data will be put in Microsoft excel then we will use E-View to analyze this data. In this study we will take the data of time series and will use the technique least square. Price and output will be determined at point when;

$$
\text { Marginal Revenue }=\text { Marginal Cost }
$$

Marginal cost can be calculated by;

$$
\mathrm{MC}=\Delta \mathrm{TC} / \Delta \mathrm{Q}
$$

Marginal revenue can be calculated by;

$$
\mathrm{MR}=\Delta \mathrm{TR} / \Delta \mathrm{Q}
$$

Total revenue and total costs can be estimated by the following function.

$$
\begin{gathered}
\mathrm{TR}=\mathrm{f}\left(\mathrm{Q}, \mathrm{Q}^{2}\right) \\
\mathrm{TC}=\mathrm{f}\left(\mathrm{Q}, \mathrm{Q}^{2}, \mathrm{Q}^{3}\right)
\end{gathered}
$$

Where $\mathrm{Q}$ is output produced, MR is marginal revenue, MC is marginal costs, TR shows total revenue of the firm and TC shows total cost. After calculating the above Total Cost and Total Revenue function we put the different value of output 0 to 5000 units and can have Total Revenue \& Total cost, Marginal revenue\& Marginal Cost values and prices.

\section{Results and Discussion}

Based on the industrial data, estimated Total Revenue and Total cost function as written as below:

$$
\begin{gathered}
\mathrm{TR}=155591+180.6697 \mathrm{Q}+0.0163 \mathrm{Q}^{2} \\
\mathrm{TC}=9152.73+239.1203 \mathrm{Q}+0.018278 \mathrm{Q}^{2}-0.0000016 \mathrm{Q}^{3 .}
\end{gathered}
$$

We have put the value of output from 0 to 5000 in above the functions and find out the values of total Revenue, Total Cost, Marginal Revenue, Marginal Cost and Prices. The output level should be 3922 where the profit of firm would be maximized. 


\section{Table 1}

\begin{tabular}{|c|c|c|c|c|c|}
\hline $\mathrm{Q}$ & $\mathrm{TC}$ & $\mathrm{TR}$ & $\mathrm{MR}$ & $\mathrm{MC}$ & $\mathrm{AR}$ \\
\hline 0 & 9152.73 & 155591 & --- & --- & --- \\
\hline 500 & 133082.4 & 250016.9 & 188.8517 & 247.8593 & 500.0337 \\
\hline 1000 & 264951 & 352624.7 & 205.2157 & 263.7373 & 352.6247 \\
\hline 1500 & 403558.7 & 463414.6 & 221.5797 & 277.2153 & 308.943 \\
\hline 2000 & 547705.3 & 582386.4 & 237.9437 & 288.2933 & 291.1932 \\
\hline 2500 & 696191 & 709540.3 & 254.3077 & 296.9713 & 283.8161 \\
\hline 3000 & 847815.6 & 844876.1 & 270.6717 & 303.2493 & 281.6254 \\
\hline 3500 & 1001379 & 988394 & 287.0357 & 307.1273 & 282.3983 \\
\hline 3700 & 1063079 & 1048092 & 298.4905 & 308.4979 & 283.2681 \\
\hline 3900 & 1124820 & 1109099 & 305.0361 & 308.7051 & 284.3844 \\
\hline 3922 & 1131611 & 1115890 & 308.6689 & 308.6702 & 284.5206 \\
\hline 3950 & 1140253 & 1124556 & 309.4871 & 308.64234 & 284.6976 \\
\hline 4000 & 1155682 & 1140094 & 310.7635 & 308.5864 & 285.0235 \\
\hline 4500 & 1309524 & 1299976 & 319.7637 & 307.6833 & 288.8835 \\
\hline 5000 & 1461704 & 1468040 & 326.3093 & 306.2585 & 293.6079 \\
\hline
\end{tabular}

In the diagram we take the output in the horizontal and take the prices in vertical axis and we show the MR curve with margin lines and MC with straight lines and AR with dots, in this diagram the equilibrium output level 3922 where the Marginal revenue is equal to marginal costs, at this point firm earn the profit and firm determine the price 285 .

\section{Figure 1}

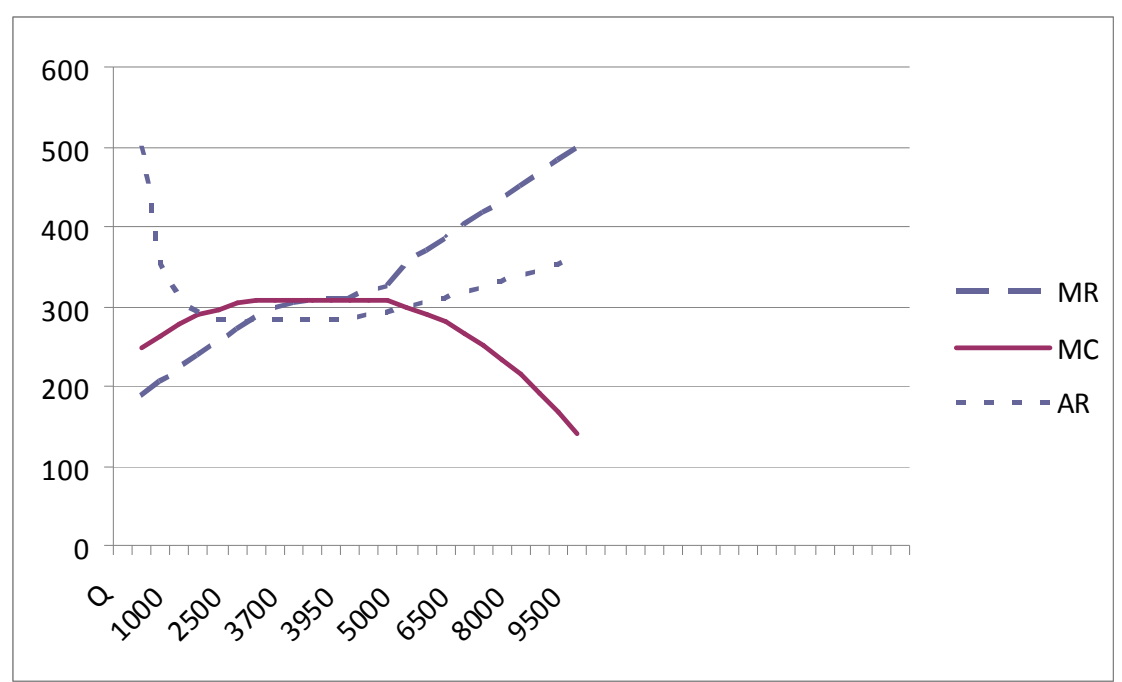

\section{Concluding Remarks}

In the study, we have concluded that firm should produce 3920 units of output where marginal revenue is equal to marginal cost. At this point, firm earns the maximum profit. We have also found total cost of the firm that is 
1131611 , total revenue is 1115890 , marginal cost is 308.6702 , marginal revenue is 308.6689 and optimum price is 284.5206 .

\section{References}

www.google.com

Www.sciencedirect.com

Hall, R.L, and Hitch, C.J. Price theory and business behavior . Oxford economics papers, May 1939, 2, 12-45 http://en.wikipedia.org/wiki/output_price level

\section{Appendix}

Table A

\begin{tabular}{|c|c|c|c|c|}
\hline \multicolumn{5}{|c|}{$\begin{array}{l}\text { Dependent Variable: TR } \\
\text { Method: Least Squares } \\
\text { Sample(adjusted): } 149 \\
\text { Included observations: } 48\end{array}$} \\
\hline \multicolumn{5}{|c|}{ Excluded observations: 1 after adjusting endpoints } \\
\hline Variable & Coefficient & Std. Error & t-Stat. & Prob. \\
\hline $\mathrm{C}$ & 155591 & 83185.63 & 1.870407 & 0.0679 \\
\hline QD & 180.6697 & 68.88954 & 2.6226 & 0.0119 \\
\hline $\mathrm{QD} * \mathrm{QD}$ & 0.016364 & 0.0081 & 2.020157 & 0.0493 \\
\hline R-squared & 0.731873 & \multicolumn{2}{|c|}{ Mean dependent var } & 541439.9 \\
\hline Adjusted R-squared & 0.719956 & \multicolumn{2}{|c|}{ S.D. dependent var } & 874600.5 \\
\hline S.E. of regression & 462831.3 & \multicolumn{2}{|c|}{ Akaike info criterion } & 28.98857 \\
\hline Sum squared resid & $9.64 \mathrm{E}+12$ & \multicolumn{2}{|c|}{ Schwarz criterion } & 29.10552 \\
\hline Log likelihood & -692.7258 & \multicolumn{2}{|c|}{ F-statistic } & 61.41545 \\
\hline Durbin-Watson stat & 2.467074 & \multicolumn{2}{|c|}{ Prob(F-statistic) } & 0.0000 \\
\hline
\end{tabular}




\section{Table B}

Dependent Variable: TC

Method: Least Squares

Sample(adjusted): 149

Excluded observations: 1 after adjusting endpoints

\begin{tabular}{|c|c|c|c|c|}
\hline Variable & Coefficient & Std. Error & t-Stat. & Prob. \\
\hline $\mathrm{C}$ & 9152.73 & 21599.8 & 0.423741 & 0.6738 \\
\hline QD & 239.1203 & 38.24534 & 6.252274 & 0 \\
\hline $\mathrm{QD} * \mathrm{QD}$ & 0.018278 & 0.011187 & 1.633861 & 0.1093 \\
\hline $\mathrm{QD} * \mathrm{QD} * \mathrm{QD}$ & $-1.60 \mathrm{E}-06$ & $7.45 \mathrm{E}-07$ & -2.153755 & 0.0367 \\
\hline R-squared & 0.970054 & \multicolumn{2}{|c|}{ Mean dependent var } & 403545.5 \\
\hline Adjusted R-squared & 0.968058 & \multicolumn{2}{|c|}{ S.D. dependent var } & 652815 \\
\hline S.E. of regression & 116673.1 & \multicolumn{2}{|c|}{ Akaike info criterion } & 26.25025 \\
\hline Sum squared resid & $6.13 E+11$ & \multicolumn{2}{|c|}{ Schwarz criterion } & 26.40468 \\
\hline Log likelihood & -639.1311 & \multicolumn{2}{|c|}{ F-statistic } & 485.9086 \\
\hline Durbin-Watson stat & 1.133852 & \multicolumn{2}{|c|}{ Prob(F-statistic) } & 0.0000 \\
\hline
\end{tabular}


The IISTE is a pioneer in the Open-Access hosting service and academic event management. The aim of the firm is Accelerating Global Knowledge Sharing.

More information about the firm can be found on the homepage:

http://www.iiste.org

\section{CALL FOR JOURNAL PAPERS}

There are more than 30 peer-reviewed academic journals hosted under the hosting platform.

Prospective authors of journals can find the submission instruction on the following page: http://www.iiste.org/journals/ All the journals articles are available online to the readers all over the world without financial, legal, or technical barriers other than those inseparable from gaining access to the internet itself. Paper version of the journals is also available upon request of readers and authors.

\section{MORE RESOURCES}

Book publication information: http://www.iiste.org/book/

Academic conference: http://www.iiste.org/conference/upcoming-conferences-call-for-paper/

\section{IISTE Knowledge Sharing Partners}

EBSCO, Index Copernicus, Ulrich's Periodicals Directory, JournalTOCS, PKP Open Archives Harvester, Bielefeld Academic Search Engine, Elektronische Zeitschriftenbibliothek EZB, Open J-Gate, OCLC WorldCat, Universe Digtial Library, NewJour, Google Scholar

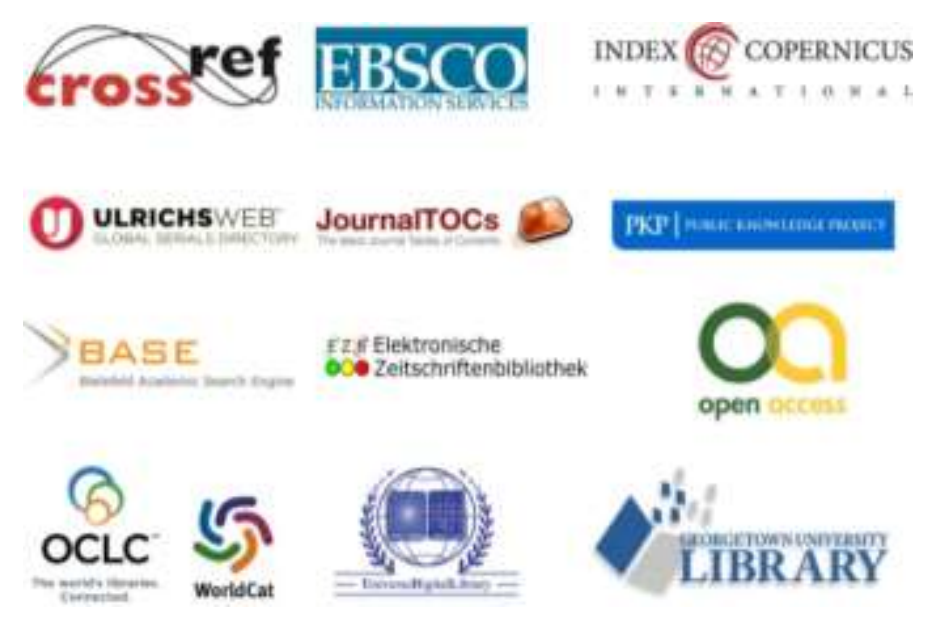

